\title{
IMPLEMENTATION AND PROTECTION OF LEGAL LAW ON CASH WAQF TOWARD TABUNG WAKAF INDONESIA OF DOMPET DHUAFA JAKARTA
}

\author{
Siti Muflichah \\ Faculty of Law Universitas Jenderal Soedirman, Indonesia \\ E-mail: lilykmuflichah@yahoo.com
}

\begin{abstract}
Waqf institution is an effort made by Muslim community and government to overcome poverty issues. One of the institutions that manage cash waqf is Wakaf Tunai Dompet Dhuafa Jakarta. Article 49 Paragraph 3 of Religious Court Law stated that the ownership of land waqf is protected and governed by the government rules This research aims to examine how the implementation and protection of waqf law on Tabung Wakaf Indonesia of Dompet Dhuafa Jakarta. This research is normative-juridical research using statute approach, conceptual approach and case approach. Then the analysis was qualitatively presented. Based on the results, the implementation of cash waqf in Tabung Wakaf Indonesia was conducted by collecting cash waqf funds to be managed into productive and non-productive activities. Tabung Wakaf Indonesia has provided legal protection to the waqif by certification of cash waqf. However, till present, there is no legitimate legality for individual cash waqf recipients or legal entities as stipulated in government regulations.
\end{abstract}

Keywords: legal protection, cash waqf, tabung wakaf Indonesia

\begin{abstract}
Abstrak
Lembaga Wakaf merupakan upaya yang dilakukan masyarakat muslim dan pemerintah secara bersama-sama dalam mengatasi masalah kemiskinan. Salah satu lembaga yang mengelola Wakaf Tunai adalah Dompet Dhuafa Jakarta. Pasal 49 ayat 3 Undangundang Peradilan Agama dinyatakan bahwa perwakafan tanah milik dilindungi dan diatur dengan peraturan pemerintah. Permasalahan yang dikaji yaitu bagaimana pelaksanaan dan perlindungan hukum wakaf pada Tabung Wakaf Indonesia Dompet Dhuafa Jakarta. Penelitian ini merupakan jenis penelian normatif dengan menggunakan pendekatan undang-undang (statute approach), pendekatan konseptual (conceptual approach) dan pendekatan kasus (case approach). Berdasarkan hasil penelitian, pelaksanaan wakaf tunai pada Tabungan Wakaf Indonesia dilakukan dengan menghimpunan dana wakaf tunai untuk dikelola menjadi kegiatan produktif dan non produktif. Tabungan Wakaf Indonesia telah memberi perlindungan hukum kepada wakif dengan dilakukan sertifikasi wakaf tunai. Namun demikian, sampai saat ini belum ditentukan legalitas hukum bagi penerima wakaf tunai perorangan atau badan hukum yang tertuang dalam peraturan pemerintah.
\end{abstract}

Kata Kunci: perlindungan hukum, wakaf tunai, tabung wakaf Indonesia

\section{Introduction}

Justice is an abstract thing; however, justice essentially demands concrete and positive action and deeds. The implementation of waqf is a concrete example of social justice since waqf is an act of giving several precious properties freely for good and prosperity. ${ }^{1}$

Waqf, according to the perspective of Islamic law (figh), is a social deed institution

Ahmad Syakir, 2016, Wakaf Produktif, available on: https://www.researchgate.net/publication/305730287_ WAKAF_PRODUKTIF, accesed on April 29 2017. which is not explicitly stated in either Quran or Sunnah. Ulama believes that the order of waqf is a part instruction to conduct al-khayr (literally means virtue). ${ }^{2}$

Waqf during the Islamic dynasties plays a significant role in state development. During Saljuk Dynasty, the waqf treasures were built for shelter of caravans passing through their

Miftahul Huda, "Arah Pembaharuan Hukum Wakaf di Indonesia", Jurnal Ulumuna, Vol. 16 No. 1, June 2016, Ponorogo: Sekolah Tinggi Agama Islam Negeri Ponorogo, page 126. 
territory; they could rest there for three days free of charge along with the available food. ${ }^{3}$ According to Islamic teachings, waqf is recommended to be implemented. Waqf is a religious service by giving up the property for the public interest and the results can be used for the social welfare.

Juridically, waqf is a legal act which may bring about the existence of separated and purposeful assets managed nazhir. Furthermore, according to Law Number 41 Year 2004 on waqf, it is stated that the legal act of wakif to separate and/or to give some of their property in order to be used forever or in a certain course of time based on the interest of worship and/or public welfare in accordance with sharia. Even though waqf plays a pivotal role to social life and has been implemented for years, in reality, waqf is not effectively functioned. These days, waqf is limited to immovable properties and intended for physical development interest such as mosque, mushalla, pesantren, graveyard and others. ${ }^{4}$

Significant number of poor people becomes proof of this. Several factors make waqf ineffectively implemented. In fact, the fundamental aim of waqf is to share virtue and kindness in terms of economic benefit for others. ${ }^{5}$

Recently, term cash waqf appears. The practice of cash waqf is confirmed with the existence of Law Number 41 Year 2004 on Waqf. It stated that waqf is not only for immovable objects but also movable objects like money. Thus, cash waqf has been recognized by positive law in Indonesia. With the existence of law on waqf, this has become a touch stone for conductive waqf empowerment.

On the other hand, the perception of Indonesian people who are syafi'iyyah figh ori-

3 P. M. Holt, Ann K. S. Lambton and Bernard Lewis, dalam Ahmad Suwaidi, "Wakaf dan Penerapannya di Negara Muslim", Economic: Jurnal Ekonomi dan Hukum Islam, Vol. 1 No. 2, Banyuwangi: STAIN Darul Ulum, page 16

4 Suryani, "Wakaf Produktif (Cash Waqf) Dalam Perspektif Hukum Islam Dan Maqașid Al-Shari'a”. Walisongo: Jurnal Penelitian Sosial Keagamaan, Vol. 24 No. 1, May 2016, Semarang: Universitas Islam Negeri Walisongo, page. 23. 5 Wawan Hermawan, "Politik Hukum Wakaf di Indonesia", Jurnal Pendidikan Agama Islam - Ta'lim, Vol. 12 No. 2, 2014, Bandung: Universitas Pendidikan Indonesia, page 147. ented hold the old understanding in the management of waqf by assuming that waqf is solely the possession of Allah, which should not be altered or final. Thus, many public figures or Muslims do not allow waqf to be managed productively except to mahdlah worship. ${ }^{6}$

The author selected Tabung Wakaf Indonesia as an object of research because it is qualified in raising and managing waqf resources productively and reliably. Article 49 Paragraph 3 Law of the Religious Court, states that waqf in ownership of land is protected and regulated by government law, then issued Government Regulation Republic of Indonesia Number 28 Year 1977 on land owned waqf (PP PTM) to follow up the mandate of Law of the Religi-ous Court. However, the implementation of Government Regulation Number 28 Year 1977 is not effective since until now there are still many waqf lands that do not have a certificate indicating that they do not have a secured legal status.

\section{Problems}

Based on the above-mentioned introduction, the question is formulated in how the implementation of cash waqf in tabung Waqf Indonesia Dompet Dhuafa Jakarta. Does it already have legal protection, what kind of type are they and what is the form of its legal protection?

\section{Research Method}

This research is a normative juridical research. The approach includes statute approach, conceptual approach and case approach. This study is a deductive research that attempts to describe the legal events and legal consequences associated with the implementation of cash waqf in Tabung Waqf Indonesia. In order to understand the in conreto incident, an interview was conducted to the fund manager of waqf at Dompet Dhuafa Jakarta. The data obtained were collected and analyzed qualitat-

\footnotetext{
Jainal Arifin, 'Problematika Perwaqfan di Indonesia (Telaah Histors dan Sosiologis)", Zizwaf: Jurnal Zakat dan Waqf, Vol. 1 No. 2, December 2014, Kudus: Sekolah Tinggi Agama Islam Negeri Kudus, page 260.
} 
ively with descriptive-analytical model, so the result can be described which related to the concept of cash waqf in Tabung Wakaf comprehensively, inclusively and systematically.

\section{Discussion}

Implementation of Cash Waqf In Tabung Wakaf Indonesia Dompet Dhuafa Jakarta

Tabung Wakaf Indonesia employs the legality of Dompet Dhuafa Republika Foundation (Dompet Dhuafa), with the Decree of the Minister of Religion of the Republic of Indonesia Number 439 Year 2001 on the Ratification of Dompet Dhuafa Republika as the National Amil Zakat Institution. Referring to Law of Republic of Indonesia Number 41 Year 2004 on Waqf, Dompet Dhuafa Republika Foundation has also been registered in Indonesian Waqf Board as Nadzir.

Tabung Wakaf Indonesia manages cash waqf distributed by the community through implementing the Law Number 41 Year 2004 on Waqf. However, it should be noted that implementation in Islam must be in accordance with the provisions in Islamic sharia, as well as implementation of cash waqf.

Implementation of cash waqf should be based on the Islamic principle as suggested in the hadith namely: "Narrated from Ibn Umar r.a. that Umar bin al-Khathab r.a. obtained the land (garden) in Khaibar, then he came to the Holy Prophet to ask for clues about the land.

He said: "O Messenger of Allah, I have acquired the land in Khaibar; which I have never acquired better treasures for me than that land, what is your command (toward me) about it?"

The Prophet replied: "If you will, you will keep the base (the land) and you give away (the yield) of it".

Ibn Umar said: "So Umar gave away the land, (by requiring) that the land was not sold, not granted and not inherited. He gives the yields of the land to the fuqara". ${ }^{7}$

In the hadith above, it explains that the principles of cash waqf property managed by Ta-

relatives, riqab (slave, oppressed), sabilillah, ibn sabil, and guests. (H.R. al-Bukhari, Muslim, al-Tirmidhi and al-Nasa "i). bung Wakaf Indonesia is a form of waqf investment funds.

Economically it can be said that waqf (Islam) is building productive property through investment activity for those who are in need set out in pledge of waqf. In the framework of developing productive waqf, money is as venture capital then the outcome will be distributed proportionally. ${ }^{8}$ Therefore, the outcome or product of waqf property can be distinguished in two parts; direct waqf and productive waqf. Direct waqf is waqf property which produces service in terms of goods to be consumed by the rightful person of waqf, such as hospital, school, orphanage, and settlement. Productive waqf on the other hand is a waqf managed for investment, production of goods and services which are permitted by Islamic law. In this matter, the capital (waqf property) is invested, and then the outcome will be distributed to those in need.

The management of waqf property, either immovable or movable waqf, has been successfully conducted by Dompet DHuafa Republika since 2001. It can be seen from its success which raised waqf funds in the amount of 86.968.000 rupiah. This fundraising increased in 2002 by gaining approximately 822.451 .600 rupiah. This increase is seemingly affected by MUI fatwa on waqf money on May $11^{\text {th }} 2002$. This condition remains the same in 2004 until present.

Money waqf managed by Dompet Dhuafa, is done by investment, whether using the profit sharing principle (mudhârabah and musyâra-kah), rent (ijârah), or murâbahah. Referring to financial management, it seems like waqf in-vestment management and funding is easier than investment. As asserted by Monzer Kahf, a new form of money waqf development through investment company refers to the money waqf of investment management in the discourse of fiqh, money waqf can be managed by the mu-dhârabah, musyârakah, ijârah as well murâba-hah investment scheme.

8 Nawawi, "Implementasi Wakaf Produktif di Indonesia Pasca Berlakunya UU No. 41 Tahun 2004 tentang Wakaf". At-Tahrir, Vol. 13 No. 2 November 2013, Ponorogo: Sekolah Tinggi Agama Islam Negeri Ponorogo, page 397. 
In performing duty as nadzir, Tabung Wakaf Indonesia manage and develop waqf property which is collected based on the purpose, function and allocation using Shari'a Islam principles. The management of money waqf which is proclaimed by Tabung Wakaf Indonesia is done based on three approaches including productive approach, non-productive approach, and integrated (combination of productive approach and non-productive approach in one object of waqf).

Firstly, productive approach. Tabung Wakaf Indonesia allocates the waqf fund for livestock business, plantation, provision of commercial facilities business and others. Based on the results from those businesses, the profit will be used for economic empowerment of the poor. According to Zaim Saidi, Tabung Wakaf Indonesia Director, allocation of money waqf to productive sectors is made to realize "tahan pokok dan nikmati hasil" principle, as said in hadith of the prophet. Waqf funds from waqif is the "primary", meanwhile the surplus from the funds is the "result". This result is allocated for program such as the construction of mosque and school. Therefore in waqf, the thing that must be carefully noticed is the fixed value of property which is represented. At the same time the waqf should produce something that can be distributed to mauquf alaih.

Secondly, non-productive approach. Based on this approach, Tabung Wakaf Indonesia manages the waqf property for unprofitable (non-productive) things. The benefit of the related waqf property is because the value can be felt by people as beneficiaries of waqf.

Thirdly, integrated approach, which is a program of waqf distribution for public service institution combined with waqf program in form of commercial facility, property, plantation, trade, agriculture, etc. The surplus of the program is distributed to poor people and/or for the operational of the institution in one program area. In the practice of financial waqf management for the productive sector, Tabung Waqf Indonesia (TWI) tends to make direct investment to the object of waqf rather than the real sector using mudhârabah, muzara'ah, dan ijârah agreement. The donation from this man- agement is distributed to many sectors such as farming, agriculture, plantation, trade, dinar and dirham selling, and trading facility waqf.

Based on Article 48 Paragraph 2 Indonesian Government Regulation No.42 year 2006 of The enforcement of Law No. 41 year 2004 of Waqf, the management and development of financial waqf should make investment on LKS products and/or the islamic financial instruments. From the perspective of TWI management, this article seems to limit the nadzir in managing the donation since it only allows the management and development of waqf conduc-ted using the islamic bank products such as de-posit or the islamic financial instrument such as mutual funds, share, and islamic obligation. Yet, according to statement of Article 1 of this regulation, the management and development of waqf should follow the BWI's rule meaning that this worry does not make sense. The rule of BWI states that the invesment of financial waqf is aimed for productive projects for peo-ple poverty through either the direct invest-ment managed by nadzir or the indirect invest-ment through islamic financial organizations such as islamic bank, BMT, islamic cooperative, etc. Thus, it means that nadzir can still make a financial waqf investment to the real sector.

Undoubtedly, the waqf financial investment on the real sector give bigger impact for the people rather than the investment on the financial sectors. Eventhough the islamic economists claim that the investment can be made on islamic financial sectors like islamic share, obligation and mutual funds, the investment on the real sector is the priority. In addition, Ahmad ibn Abdul Azîz al-Hadâd, in his book Waqf al-Nuqûd wa Istitsmaruhâ, explained that the best financial waqf development is on the trade sector. It is in line with the statement of Dian Masyita who stated that the development can be conducted by making direct investment on big and medium enterprises. The nadzir allocates the donation on some big companies in form of shares which then result in capital gain in a long time. This way of investment undoubtedly give more positive impact to the economical empowerment of the society though it has small percentage. 
Tabung wakaf Indonesia is the main productive nadzir waqf in Indonesia whose duties is receiving waqf money from community. In doing their duties as nadzir, Tabung Wakaf Indonesia manage and develop waqf property collected along with purposes, function and their sharia Islamic principle. Asset management in Tabung Wakaf Indonesia done by two approaches: productive approach, and non-productive approach. While in waqf management, they use asset management pattern, which consider waqf to result in surplus. Tabung Wakaf Indonesia's slogan is goose lay gold. The goose could not be dead; hence, its eggs can be used for community welfare. Waqf money will be invested in real sector. Therefore, its result will distribute through productive social programs. What Tabung Wakaf Indonesia perform as nadzir institution viewed from maqasid al-Syariah, enable them to implement three purposes of Islamic law by Syeh Muhamad Abu Zahra in Sapiudin Sidiq, namely: first, Guide each individual to be a source of kindness for everyone which can be accomplished through prescribed religious service, such as shalat. This is in accordance with Q.S Al Ankabut (29): 45 which means: “...Indeed, prayer prohibits immorality and wrongdoing, and the remembrance of Allah is greater merit.". ${ }^{9}$ Second, Uphold justice in community either within Muslim or with non-Muslim as stated in Q.S Al-Maidah (5):8 which means: “...Do justice, that is nearer to taqwa. And fear Allah. Surely, Allah is all-aware of what you do."

Viewed from ushul fiqih Tabung Wakaf Indonesia al-kulliyatul khas (five principal pillars) or maqasid asy-syariah (universal sharia purposes), Tabung Wakaf Indonesia could help wakif to realize Hifdz al-dien (guranteed religion freedom) and Hafidz al-nasl (guaranteed generation and honor). Welfare parameter refers to ushul figh doctrine which also known as al-kulliyatul khas (five principal pillars) or maqasid asy-syariah (universal sharia purposes), they are:10 first, Hifdz al-dien, guaranteed freedom of religion; second, Hifdz al-nafs,

\footnotetext{
Majlis Wakaf dan ZIS Pimpinan Pusat Muhamadiyah, 2010, Panduan Wakaf, Jakarta: Majlis Wakaf dan ZIS 10 Ibid
}

maintain life continuity; third, Hifdz al-aql, guaranteed creativity of thinking; fourth, Hifsz al-nasl, guaranteed generations and honor; fifth, Hifdz al-mal, ownership of properties and wealth. Law Number 41 year 2004 of waqf, give flexibility for Muslim to participate in waqf program even they are not rich yet. They could save some of their wages for waqf cash or give their properties gradually. This is a new innovation as a chance to enhance the prosperous Muslims.

Till present Tabung Wakaf Indonesia does not have written System Operation Procedure as principal for organization and control the organization performance in doing their target. As admitted by manager program of $\mathrm{Ta}$ bung Wakaf Indonesia, Hendra Jatnika, despite its reality, each manager keep performing their duties as their responsibility. He added that development of money collected by Tabung Wakaf Indonesia as asset always increases and successful. As organization that manages public funds as Management Corporation; System Operation Procedure is definitely needed. Hence, organization could reach their purposes and target also control and assessment of organization can be conducted. The function of planning in managing waqf funds is the first step of managing activity. Every management activity need planning and function of organization that take a big role in manage waqf funds. ${ }^{11}$

In Islamic law, main waqf must exist and everlasting. If it is cash waqf, that waqf has to be used for beneficial things and its main value must exist; therefore, its benefits can be everlasting. Nowadays Muslim society is still debating on the management of zakat and productive waqf. Some Muslims doubt that if zakat and waqf are managed productively, they will increase the beneficial value of these two institutions. ${ }^{12}$

Tabung Wakaf Indonesia as nadzir (waqf administrator) is responsible for keeping cash waqf sustainable. Hence, Tabung Wakaf Indone-

11 Fahmi Medias, "Paradigma Baru Manajemen Dana Wakaf di Indonesia”, Rasail, Vol. 1 No. 2. 2014, Yogyakarta: Sekolah Tinggi Ekonomi dan Bisnis Islam, page 166.

12 Muslihun, "Dinamisasi Hukum Islam di Indonesia Pada Zakat Produktif dan Wakaf Produktif: Sebuah Studi Perbandingan", Almanahij, Vol. 8 No. 2 2014, Purwokerto: Institut Agama Islam Negeri Purwokerto, page 14. 
sia can conduct the things which are able to protect the managed waqf by determining certain necessary strategies. In this case, this institution can conduct it through ijtihad way (serious hard effort) without necessarily be attached to the standard law system either in Quran or As-Sunnah. ${ }^{13}$ Imam Malik stated "Ratio must be noticed for the consideration of Al-Mashalih AlMursalah welfare", as it was delivered by Ibrahim Husen that Mashalih Al-Mursalah becomes the legal principle. He thought that Mashalih Al-Mursalah approach needs to be conducted in legal cases since people welfare is not the same and it has many varieties; moreover, it always develops and changes over time.

Supervision and protection of waqf properties are aimed at preventing the value decrease of waqf properties either because of force majeure events or loss and failure of investment. Prudential principle of investment must be clung firmly; thus, waqf properties are managed based on the rule of waqf management in Islamic way. The value of waqf properties is anticipated not to decrease. Jalaluddin al-Mahally affirmed that in managing and developing waqf properties, nadzir has to maitain waqf properties and their results thoroughly.

\section{Conclusion}

The implementation of cash waqf in Tabung Wakaf Indonesia is performed by collecting cash waqf through several ways and its management is done either productively and non-productively. Tabung Wakaf Indonesia has given adequate legal protection to wakif since certification of cash waqf is conducted based on the stipulation regulated in Article 62 of Law Number 41 of 2004. However, law legality for cash waqf recipients either individual or legal entity has not been determined in governmental regulation.

\section{Suggestion}

A written System Operation Procedure is required as reference and guidance for organization to control organization's performance in achieving goal and target. Therefore, or- ganization can run well in accordance with the goal and the target that have been determined by the organization itself.

\section{References}

Arifin, Jainal. 'Problematika Perwakafan di Indonesia (Telaah Histors dan Sosiologis)". Zizwaf: Jurnal Zakat dan Wakaf. Vol. 1 No. 2. December 2014. Kudus: Sekolah Tinggi Agama Islam Negeri Kudus;

Hermawan, Wawan. "Politik Hukum Wakaf di Indonesia". Jurnal Pendidikan Agama IslamTa'lim. Vol. 12 No. 2 2014. Bandung: Universitas Pendidikan Indonesia;

Huda, Miftahul. "Arah Pembaharuan Hukum Wakaf di Indonesia". Jurnal Ulumuna. Vol. 16 No. 1. June 2016. Ponorogo: Sekolah Tinggi Agama Islam Negeri Ponorogo;

Majlis Wakaf dan ZIS Pimpinan Pusat Muhamadiyah. 2010. Panduan Wakaf. Jakarta: Majlis Wakaf dan ZIS Pimpian Pusat Muhamadiyah;

Medias, Fahmi. "Paradigma Baru Manajemen Dana Wakaf di Indonesia". Rasail. Vol. 1 No. 2. 2014. Yogyakarta: Sekolah Tinggi Ekonomi dan Bisnis Islam;

Muslihun. "Dinamisasi Hukum Islam di Indonesia Pada Zakat Produktif dan Wakaf Produktif: Sebuah Studi Perbandingan". Almanahij. Vol. 8 No. 2 2014. Purwokerto: Institut Agama Islam Negeri Purwokerto;

Nawawi. "Implementasi Wakaf Produktif di Indonesia Pasca Berlakunya UU No. 41 Tahun 2004 tentang Wakaf". At-Tahrir. Vol. 13 No. 2. November 2013. Ponorogo: Sekolah Tinggi Agama Islam Negeri Ponorogo;

Suryani. "Wakaf Produktif (Cash Waqf) Dalam Perspektif Hukum Islam Dan Maqașid AlShari'a". Walisongo: Jurnal Penelitian Sosial Keagamaan. Vol. 24 No. 1. May 2016. Semarang: Universitas Islam Negeri Walisongo;

Suwaidi, Ahmad. "Wakaf dan Penerapannya di Negara Muslim" Economic: Jurnal Ekonomi dan Hukum Islam. Vol. 1 No. 2. Banyuwangi: STAIN Darul Ulum;

Syakir, Ahmad. 2016. Wakaf Produktif. Available on: https://www. researchgate.net/ publication/305730287_WAKAF_PRODUKTI F. Accessed on April $29^{\text {th }} 2017$.

13 Ahmad Suwadi, Op.Cit, page 160. 